INSIGHTS INTO REGIONAL DEVELOPMENT

ISSN 2669-0195 (online) http://jssidoi.org/IRD/

2020 Volume 2 Number 4 (December)

http://doi.org/10.9770/IRD.2020.2.4(4)
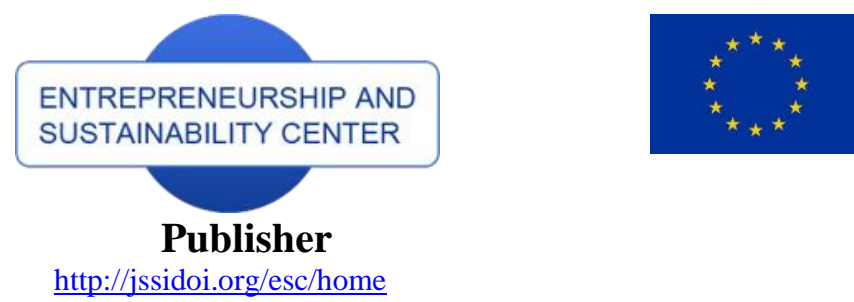

\title{
STRATEGIES TO MANAGE THE RISKS FACED BY CONSUMERS IN DEVELOPING E- COMMERCE
}

\author{
Kiran Javaria ${ }^{\text {, }}$ Omar Masood ${ }^{2}$, Fernando Garcia ${ }^{3}$ \\ 1, 2, School of Accountancy and Finance, University of Lahore, Islamabad, Pakistan \\ ${ }^{3}$ Department of Economics and Social Sciences, Universitat Politecnica de Valencia, Valencia, Spain \\ E-mails: ${ }^{1}$ kiranmaryam23@gmail.com; ${ }^{2}$ masood_omar@hotmail.com; ${ }^{3}$ fergarga@esp.upv.es
}

Received 18 July 2020; accepted 25 September 2020; published 30 December 2020

\begin{abstract}
The study investigates the management of risk in E-Commerce and what different barriers are faced by consumers during an uncertain and risky situation. The study utilizes both primary and secondary data in order to get reliable results. There are different risk factors that affect the purchasing behaviour of consumers who shop online. The consumer's perception of risk may be the result of all the emotional processes through which consumers recognize, organize and provide meaning to sensations received, such as the need for product quality, safety online and overall satisfaction. The primary data consists of a survey of online shoppers. The research data and questionnaire was administered to 972 internet users who are classed as experienced and avid users. The secondary data includes an analysis of the various theories of consumer behaviour, models of online adoption, risk factors to marketing and shopping online, models of the adoption of innovation and new ways of marketing and trade. Both techniques are utilized that would examine the relationship between perceived risk strategies and customer satisfaction as well as examined the customer involvement and propensity to take risk on existing relation of online shopping.
\end{abstract}

Keywords: E-commerce; risk management; financial manager; perceived risk strategies; customer satisfaction; customer involvement; propensity to take risk

Reference to this paper should be made as follows: Javaria, K., Masood, O., Garcia, F. 2020. Strategies to manage the risks faced by consumers in developing e-commerce. Insights into Regional Development, 2(4), 774-783. http://doi.org/10.9770/IRD.2020.2.4(4)

JEL Classifications: G32, Z33, M31

\section{Introduction}

In today's competitive environment, technology is the most efficient means through which organization communicate, keep themselves in touch with market and gained competitive advantage. E-Commerce shopping or buying through internet is one of the rapid growing phenomenon (Lim, Osman et al, 2016). It is important for the E-retailers to maintain customer repurchase intention and sustain operations in order to gain competitive advantage in the market (Darsono et al. 2019). In an e-Commerce world it is important for the service provider to 


\section{INSIGHTS INTO REGIONAL DEVELOPMENT}

ISSN 2669-0195 (online) http://jssidoi.org/jesi/

2020 Volume 2 Number 4 (December)

http://doi.org/10.9770/IRD.2020.2.4(4)

engage with customers and provide them security from all the risks faced by online consumers. Kim \& Hong (2010) and Cunningham et al (2005) examined the impact on the adoption of the purchase through the Internet and have outlined them as: financial risk, functional, social and physical environment, incorporating the fifth dimension of this specific sales system, the risk of privacy. Kim et al (2005) contrasts the opposite effect, by detecting a significant effect of dimensions of risk on purchase intention via the Internet but not their attitudes toward such behaviour. Based on the work of Gierl et al (2003) analyzed the effect of six dimensions of perceived risk on the adoption of electronic commerce. In particular, these authors refer to functional components, financial, time, psychological, and social and privacy arguing that the latter replaces the physical risk in electronic environment. The Empirical evidence supports the influence gained in all dimensions, except social intention of adoption of electronic commerce (Bianchi \& Mathews, 2016).

The main motivation of this research is that it strongly contributes to the lack of available research materials on marketing risk. Despite the quantity of published studies on the subject, including several reviews (Mitchell et al, 1990; Laroche et al., 2004), most of research in this area focuses on the perception of risk in relation to categories of products, disregarding the means to purchase and customer satisfaction. The present study provides major contribution in e commerce technology world. The aims of this research is to study the concept of risk in marketing in e-commerce world as there is currently insufficient research studies on the concept despite its critical importance in influencing the behaviour of consumers. The analysis of risk has been a field without boundaries in academia, it has been investigated in areas such medicine, social sciences, among others (Klein; Sterk, 2003). It is stated by many researchers that e-commerce shopping is one of the most rapid growing phenomenon's nowadays (Lim, Osman et al, 2016). This area of knowledge has a great influence on theories of marketing, especially in the analysis of consumer behaviour. The aim of the study is to identify the different theories and dimensions of risks by consumers as they purchase through e-commerce and analyze the efforts of the consumer, through the strategies of reducing the risk, in the process of purchase through e-commerce and measure consumer satisfaction in the process of buying.

This paper is divided into four parts. $2^{\text {nd }}$ part will give the literature review which explains different types of risk reduction strategies and its impact on customer satisfaction and also supports with theoretical background. $3^{\text {rd }}$ part demonstrates the research methodology of the paper. $4^{\text {th }}$ part will give empirical analysis and $5^{\text {th }}$ part will finally conclude with recommendations.

\section{Literature Review}

\subsection{Theoretical Background}

The theory "Effort in Purchase" proposed by Laroche et al (2004), it is suggested that the greater the effort of consumers in a particular purchase, the greater would be the perception of satisfaction with the purchase process. Thus, the perception of the outcome of the bid would be shaped in accordance with the effort invested (Sobihah et al, 2015). This theory supports this study and explained that individuals tend to perceive a measure of satisfaction as a result of efforts expended on the search of an item. It is emphasized that the degree of involvement with the purchase has an influence on risk perceived by consumers and reduction strategies leading to the perception of satisfaction with the purchase process. There are many studies conducted on consumer online purchase (McCole et al., 2010). One consumer purchasing a product in different situations or different products may have a greater or lesser perception of risks (Park, Bhatnagar \& Rao, 2010). 
INSIGHTS INTO REGIONAL DEVELOPMENT

ISSN 2669-0195 (online) http://jssidoi.org/jesi/

2020 Volume 2 Number 4 (December)

http://doi.org/10.9770/IRD.2020.2.4(4)

\subsection{Relationship analysis}

\subsubsection{Risk in online marketing effect on consumer satisfaction to purchase}

Evidence supporting the influence of risk on the behaviour of consumers who shop online has been highlighted by numerous authors in the field. The attitude of online buyers significantly and positively affects customer satisfaction and their online purchasing behaviour. Internet-based transactions, management of consumers' risk is very important. Sobihah et al, (2015) analyzed the effect of uncertainty about the product (risk functional) and the shipping process (source of risk) on the adoption of trade. For its part, the empirical evidence obtained by Lim (2003) observed that the guarantees of privacy positively affect the confidence in purchasing on the Web, and through its intended behaviour (Choi, Kim \& Kim, 2011). There are various types of risk which are defined respectively:

Financial Risk: Pires et al (2004) states that financial risk has been employed in studies that relates to the loss of economic capital by the consumer, or by purchase and / or use of the product or service purchased. It is the risk that the product is not worth the cost (Schiffman; Kanuk, 1997), and a broader definition, the financial risk is at any risk related to loss of property and money (Solomon, 1998).

Risk of Performance and functional: Bateson and Hoffman (2001) explain that, the concept that the product or service purchased may not correspond to the task for which it was purchased. The risk functional, or performance, is risk that the product does not have the expected performance. It can be mitigate through customer satisfaction (Sobihah et al, 2015).

Physical Risk: The physical risk is associated with lack of physical tangibility of the products before purchase (Solomon, 1998), especially since some products are dangerous to health or security and, when they fail, can lead to physical danger (Weber et al, 2004).

Risk of time: The risk of time was defined as the possibility of a purchase that is likely to be prolonged without getting the expected benefits or lack of motivation on the product as a result of a time lapse, associated with the inefficient use of time caused by the product (Son \& Han, 2011).

\subsubsection{Risk Mitigation Strategies in online electronic commerce:}

There are various strategies which organization can use to minimize the risk of online electronic commerce (Lim, Osman et al, 2016). These strategies are given below:

Online Networking: A strategy to reduce the risk perceived by the search for information can be minimized through online networking sites which lots of consumers subscribe to where information is shared on product reviews, (Kim, 2005). The benefit of this is that the network provides reviews of customers around the world, quickly and without cost online, (Kuo et al., 2013).

Search for online reviewers and rating system: In a study conducted by $\mathrm{Wu}$ et al (2004), the results indicate that major strategies for risk reduction strategies with regards to high product ratings of the purchase are: firstly the group of reference (except for products of high perceived risk, which would, in this case, the image of mark), followed by retailer's reputation, the brand image and guarantees (Lim, Osman et al, 2016).

\subsubsection{The involvement of consumer (as a Moderator):}

One of the aspects mentioned in the literature of consumer behaviour is the influence in purchasing decisions and the individual's involvement with the process, product, and brand (Solomon, 2002). The consumer's involvement is defined as the perceived relevance of an individual on an object based on their needs, values and interests (Ranaweera, 2016). Corroborating with this idea, Engel et al. (1995) comments that this involvement increases when the social pressure is perceived, i.e. the extent to which consumers feel they will be judged by an 
INSIGHTS INTO REGIONAL DEVELOPMENT

ISSN 2669-0195 (online) http://jssidoi.org/jesi/ 2020 Volume 2 Number 4 (December)

http://doi.org/10.9770/IRD.2020.2.4(4)

acquisition, involvement tends to be higher (Sobihah et al, 2015). The involvement can be seen as the motivation to process information in that, to where there is a connection between the perceived needs, goals or values of and knowledge of consumer product, the individual will be motivated to pay attention in information about this (Mou, Shin, Cohen. 2015).

\subsubsection{The propensity to take risk (as a Moderator)}

The propensity to take risks is an individual characteristic as stated by Engel et al (1995) who states, there are segments of consumer who love to take risks, or risk hunters or thrill seekers. Another finding from the survey suggests that that the risk takers were quite prevalent among young people, ranging from 16 to 24 years, with declining age (Mercado \& Rajagopal, 2015). Thus, the search of sensations is a characteristic of personality, related to diverse experiences, new and complex and their willingness to accept risks for experiencing them. In choosing the Internet as a channel for the acquisition, the searches for sensations influence these decisions (Mercado \& Rajagopal, 2015).

\subsubsection{Customer satisfaction as way to reduce customer risk}

The satisfaction of the consumer is considered one of the central themes of the concept of marketing. Companies now back up, increasingly, for the client and the majority this includes, indeed, the need to satisfy the consumer, especially due to more fierce competition in the market (Sobihah et al, 2015). Satisfaction is considered the largest output of the marketing activity and serves as a liaison between the process of purchasing and consumption, which culminates with the phenomena of post-purchase, such as a change of attitude, repeat purchase and brand loyalty (Mercado \& Rajagopal, 2015). Thus, the satisfaction of the consumer has been seen as a crucial factor for the success of organizations by directly influence behaviours such as brand loyalty, announced positive mouth to mouth, repeat purchases, and, consequently, greater market share and profitability (Oliver, 1997) (Sobihah et al, 2015). Theoretical framework is presented in Figure 1 below.

Figure 1: Theoretical framework

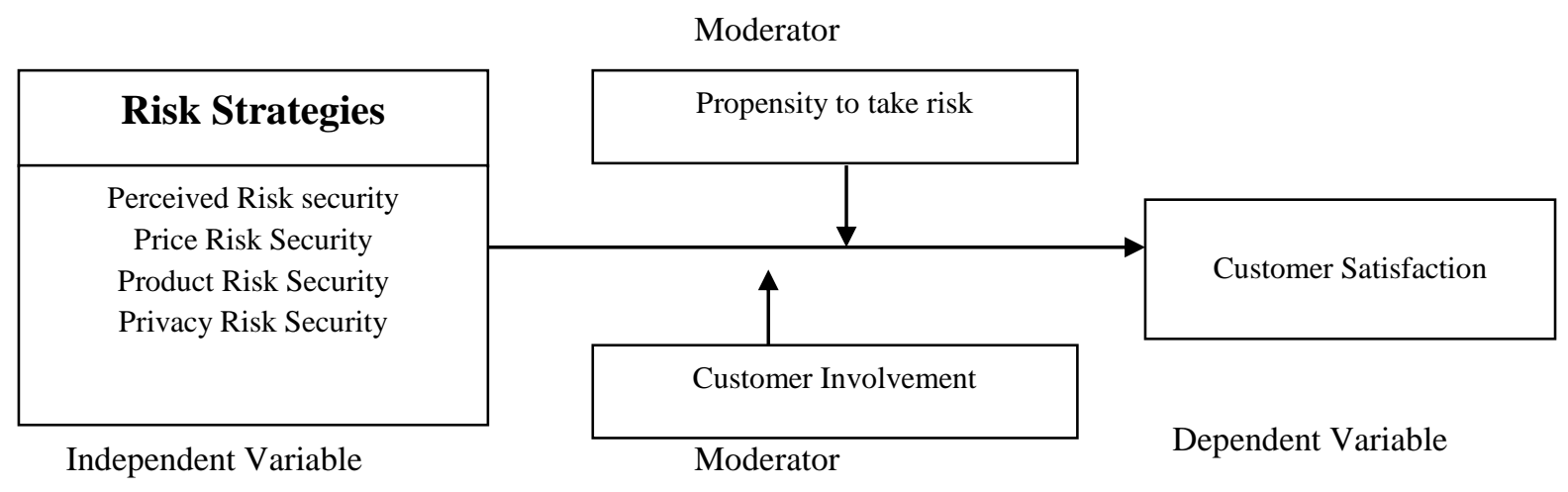

\section{Hypotheses Development:}

H1: The risk reduction strategies have significant and positive impact on customer satisfaction in e-commerce

H1a: The Perceived Risk strategies have significant and positive impact on customer satisfaction in e-commerce

H1b: The Price Risk strategies have significant and positive impact on customer satisfaction in e-commerce

H1c: The Product Risk strategies have significant and positive impact on customer satisfaction in e-commerce

H1d: The Privacy Risk strategies have significant and positive impact on customer satisfaction in e-commerce

H1e: The Time Risk strategies have significant and positive impact on customer satisfaction in e-commerce 
INSIGHTS INTO REGIONAL DEVELOPMENT

ISSN 2669-0195 (online) http://jssidoi.org/jesi/

2020 Volume 2 Number 4 (December)

http://doi.org/10.9770/IRD.2020.2.4(4)

H2: The involvement moderate the relationship between risk reduction strategies and customer satisfaction in e-commerce

H2a: The involvement moderate the relationship between Perceived Risk strategies and customer satisfaction in e-commerce

H2b: The involvement moderate the relationship between Price Risk strategies and customer satisfaction in e-commerce

H2c: The involvement moderate the relationship between Product Risk strategies and customer satisfaction in e-commerce

H2d: The involvement moderate the relationship between Privacy Risk strategies and customer satisfaction in e-commerce

H2e: The involvement moderate the relationship between Time Risk strategies and customer satisfaction in e-commerce

H3: The propensity to take risk moderate the relationship between risk reduction strategies and customer satisfaction in ecommerce

H3a: The propensity to take risk moderate the relationship between Perceived Risk strategies and customer satisfaction in e-commerce

H3b: The propensity to take risk moderate the relationship between Price Risk strategies and customer satisfaction in e-commerce

H3c: The propensity to take risk moderate the relationship between Product Risk strategies and customer satisfaction in e-commerce

H3d: The propensity to take risk moderate the relationship between Privacy Risk strategies and customer satisfaction in e-commerce

H3e: The propensity to take risk moderate the relationship between Time Risk strategies and customer satisfaction in e-commerce

\section{Research Methodology}

Present research methodology used quantitative based approach and study utilized triangulation method for data collection. In triangulation method researcher used different data source to validate the results. In this study researcher utilized three methods which includes: Primary data collection and interviews from online shoppers of Pakistan and also used Secondary data collection (Theoretical Support).Primary data consist of a survey of online shoppers. The data collection instrument of this phase was a semi-structured script. Questionnaires and interviews are administered to a sample segment of the population of consumers who shop online from different online website in Pakistan (like OLX, daraz.pk, Alibaba etc). The question for online website was an open ended questionnaire. The secondary data included a literature review from the main academic research portals which includes an analysis of the various theories of consumer behaviour, models of online adoption. The research data and questionnaire was administered to 972 internet users who are classed as experienced and avid users. Their pattern of usage includes: A 38\% daily, 52\% regularly and 10\% rarely. Of those surveyed, $79 \%$ have already purchased online. Based on the sample evidence, 5 of 7 risk women faced a greater risk than men in the form of online harassment. 35\% of those interviewed have suffered some kind of harassment while internet chatting. For each risk criterion, women have a perception of risk far greater than men for all risks, except the security risk where there is no difference between the sexes. In all the risk factors considered, age was also an important distinguishing factor, so at the age is higher than the perceived risk is strong. In a first phase, the questionnaire was tested with a dozen people. This pre-test allowed us to change the wording of some questions or statements. Thereafter, 2 modes of distributions have been made. First researcher used pilot testing for questionnaire validation and then distributed 1000 questionnaire among responded. 972 respondents filled the questionnaire, so the response rate was $97 \%$. Researcher utilized three means of sources for present research validation. First researcher used secondary data in which theories and literature were used to support the results then researcher utilized survey method in which questionnaire and interviews were conducted from customers. Questionnaires were distrusted among the respondent and as mentioned above the response rate was $97 \%$. Other source was interview with 20 customers who were internet users and frequently utilized internet tool for their online shopping from different online website in Pakistan (like OLX, daraz.pk, Alibaba etc). So basically researcher used triangulation technique in order to analyze the present research data set.

\section{Empirical Analysis}

\subsection{Validation and Robustness of Regression Model}

Validity of present study shows that findings truly represent the present study phenomena. Study finds out Eign value which is 0.566 and it is less than 1 . (Eign value <1) shows that data is valid in nature. Percentage of variance should be less than $50 \%$ and present study percentage of variance is less than fifty. F statistics of at least 3.95 is needed to accept alternative hypothesis. Present study model F statistics value is 96.23 shows overall 
INSIGHTS INTO REGIONAL DEVELOPMENT

ISSN 2669-0195 (online) http://jssidoi.org/jesi/ 2020 Volume 2 Number 4 (December)

http://doi.org/10.9770/IRD.2020.2.4(4)

significance of regression model. Present study utilized model of risk management strategies and their impact on customer satisfaction is overall significant.

4.2. Correlation Analysis (see Table 1)

Table 1: Correlation Analysis of Variables

\begin{tabular}{|c|c|c|c|c|c|c|c|c|c|c|}
\hline Variables & $\mathbf{M}$ & SD & PerR & PriR & ProR & PrivR & TR & PTR & CI & CS \\
\hline $\begin{array}{ll}\text { Perceived } & \text { Risk } \\
\text { Security } & \end{array}$ & 1.946 & 0.667 & 1 & & & & & & & \\
\hline Product Risk Security & 1.916 & 0.634 & $0.711^{*}$ & $0.636^{*}$ & 1 & & & & & \\
\hline Time Risk Security & 2.199 & 0.946 & $0.493^{*}$ & $0.406^{*}$ & $0.536^{*}$ & $0.477 *$ & 1 & & & \\
\hline $\begin{array}{l}\text { Propensity to take } \\
\text { Risk }\end{array}$ & 1.846 & 0.567 & $0.741^{*}$ & $0.627^{*}$ & $0.722 *$ & $0.556^{*}$ & $0.759 *$ & 1 & & \\
\hline $\begin{array}{l}\text { Customer } \\
\text { Involvement }\end{array}$ & 2.167 & 0.886 & $0.721 *$ & $0.788^{*}$ & $0.536^{*}$ & $0.453^{*}$ & $0.666^{*}$ & $0.677^{*}$ & 1 & \\
\hline
\end{tabular}

Description: Correlation and descriptive analysis are one of the important analysis technique used to determine the association among independent and dependent variables and it also explains that how much one variable depends on other variable. In present study, correlation analysis shows that all variable correlation value lies within range $(\mathrm{CA}<0.80)$ so it is stated that all variable acts independently and can use for further analysis.

\subsection{Regression Analysis:}

After determining relationship between variables through correlation, regression analysis is used to assess the cause and effect relationship between dependent and independent variable. It determines that how much change in dependent variable is caused by independent variables. Below mention regression model equations which are used by researcher for present study.

\subsubsection{Equation for Customer Involvement Interaction Term}

Customer Satisfaction $=\alpha+\beta_{1}$ (Perceived Risk Security $)+\beta_{2}($ Customer Involvement $)+\beta_{3}($ Interaction PerR_CI $)+e$

Customer Satisfaction $=\alpha+\beta_{1}$ (Price Risk Security $)+\beta_{2}($ Customer Involvement $)+\beta_{3}($ Interaction PerR_CI $)+e$

Customer Satisfaction $=\alpha+\beta_{1}$ (Product Risk Security) $+\beta_{2}($ Customer Involvement $)+\beta_{3}$ (Interaction ProR_CI $)+e$

Customer Satisfaction $=\alpha+\beta_{1}$ (Privacy Risk Security) $+\beta_{2}($ Customer Involvement $)+\beta_{3}($ Interaction PrivR_CI $)+e$

Customer Satisfaction $=\alpha+\beta_{1}$ (Time Risk Security) $+\beta_{2}($ Customer Involvement $)+\beta_{3}$ (Interaction TR_CI $)+e$

\subsubsection{Equation for Propensity to take Risk Interaction Term}

Customer Satisfaction $=\alpha+\beta_{1}$ (Perceived Risk Security $)+\beta_{2}($ Propensity to take Risk $)+\beta_{3}($ Interaction PerR_PTR $)+e$ Customer Satisfaction $=\alpha+\beta_{1}$ (Price Risk Security) $+\beta_{2}$ (Propensity to take Risk) $+\beta_{3}$ (Interaction PerR_PTR) $+e$ Customer Satisfaction $=\alpha+\beta_{1}$ (Product Risk Security) $+\beta_{2}$ (Propensity to take Risk) $+\beta_{3}$ (Interaction ProR_PTR) $+e$ Customer Satisfaction $=\alpha+\beta_{1}$ (Privacy Risk Security) $+\beta_{2}$ (Propensity to take Risk) $+\beta_{3}$ (Interaction PrivR_PTR) $+e$ Customer Satisfaction $=\alpha+\beta_{1}$ (Time Risk Security) $+\beta_{2}$ (Propensity to take Risk) $+\beta_{3}$ (Interaction TR_PTR) $+e$

In this equation, 'e' is the error term that measures influence of variables other than independent variables (see Table 2). 
INSIGHTS INTO REGIONAL DEVELOPMENT

ISSN 2669-0195 (online) http://jssidoi.org/jesi/

2020 Volume 2 Number 4 (December)

http://doi.org/10.9770/IRD.2020.2.4(4)

Table 2: Regression Analysis

\begin{tabular}{llllll}
\hline & $\begin{array}{l}\text { Un-standardized } \\
\text { Coefficient }\end{array}$ & $\begin{array}{l}\text { Standardized } \\
\text { Coefficient }\end{array}$ & & & \\
\hline Variables & Beta & Beta & T & Sig & VIF \\
\hline Constant & 0.002 & & 0.036 & 0.024 & 3.048 \\
Z score (PerR) & 0.225 & 0.225 & 2.662 & 0.009 & 2.096 \\
Z score (PriR) & 0.192 & 0.192 & 2.736 & 0.007 & 3.352 \\
Z score (ProR) & 0.457 & 0.457 & 5.150 & 0.000 & 1.721 \\
Z score (PrivR) & 0.049 & 0.049 & 2.333 & 0.000 & 2.096 \\
Z score (TR) & 0.236 & 0.236 & 2.556 & 0.003 & 3.352 \\
Z score (CI) & 0.224 & 0.224 & 4.323 & 0.000 & 1.721 \\
Z score (PTR) & 0.344 & 0.344 & 0.772 & 0.000 & 3.497 \\
InteractionPerR_CI & 0.051 & 0.063 & 0.698 & 0.000 & 2.593 \\
InteractionPri_CI & 0.080 & 0.087 & 1.109 & 0.000 & 2.994 \\
InteractionPro_CI & 0.017 & 0.025 & 0.298 & 0.001 & 2.096 \\
InteractionPriv_CI & 0.246 & 0.226 & 5.150 & 0.000 & 3.352 \\
InteractionTR_CI & 0.254 & 0.244 & 2.333 & 0.003 & 1.721 \\
InteractionPer_PTR & 0.090 & 0.087 & 2.556 & 0.000 & 2.096 \\
InteractionPri_PTR & 0.017 & 0.025 & 4.323 & 0.000 & 3.352 \\
InteractionPro_PTR & 0.226 & 0.226 & 0.772 & 0.002 & 1.721 \\
InteractionPriv_PTR & 0.070 & 0.087 & 0.698 & 0.003 & 3.497 \\
InteractionTR_PTR & 0.087 & 0.085 & 1.109 & 0.000 & \\
\hline
\end{tabular}

\section{Description}

Study shows that beta value of all variables shows strong relationship between risk strategies and customer satisfaction and also shows the moderators impact on present relationship. Results of present study explains that all relationships are significant in nature as all variables $\mathrm{z}$ score $\mathrm{P}$ values are less than 0.05 which shows that hypothesis H1a, H1b, H1c, H1d and H1e are accepted and perceived price, products, privacy and time risk securities have significant impact on customer satisfaction. Interaction terms of customer involvement and Propensity to take Risk are also significant which shows that hypothesis $\mathrm{H} 2$ and $\mathrm{H} 3$ all dimensions are accepted. Customer involvement and Propensity to take Risk significantly influence the relationship between risk strategies and customer satisfaction.

\subsection{Interviews Interpretation}

Another data source was interviews which were conducted from 20 customers who were internet users and frequently utilized internet tool for their online shopping. Interview was conducted to a sample segment of the population of consumers who shop online from different online website in Pakistan (like OLX, daraz.pk, Alibaba etc). There was open choice for consumer to select any website during their interview. The basic purpose was to check their customer satisfaction and how it was affected by different risk strategies. Results of interviews show that:

There was a consensus from $70 \%$ of the respondents of the dangers of online shopping with tales of woes from the respondents from lists of stolen card numbers. The reason cited by users for to not shop online is the fear of online payment. (Perceived Risk). 77\% of the respondents interviewed, stated that laptops and other very expensive items was what constituted the risk of the product, but there was much lower risk to the product on account of very low quality e.g. a book and were less apprehensive to price risk (Price Risk). 55\% of the respondents affirmed greater risk to the product on account of very low quality. (Product Risk). For $85 \%$ of the respondents interviewed had recorded negative outcomes with regards to security risk. The respondents stressed on the difference in safety with a physical store. 35\% of those interviewed have suffered some kind of harassment while internet chatting. (Privacy Risk). 59\% of the respondents cited their instances of wasted time on the internet 
INSIGHTS INTO REGIONAL DEVELOPMENT

ISSN 2669-0195 (online) http://jssidoi.org/jesi/ 2020 Volume 2 Number 4 (December)

http://doi.org/10.9770/IRD.2020.2.4(4)

spent comparing products between different sites and spends more time in this type of search on a single site. (Time Risk). (See Table 3).

Table 3: Summary of Result

\begin{tabular}{|c|c|c|c|}
\hline Hypotheses & Results & P-value & $\begin{array}{l}\text { Reason } \\
\text { rejection }\end{array}$ \\
\hline $\begin{array}{l}\text { H1a: The Perceived Risk strategies have significant and positive } \\
\text { impact on customer satisfaction in e-commerce }\end{array}$ & Accepted & 0.009 & Significant \\
\hline $\begin{array}{l}\text { H1b: The Price Risk strategies have significant and positive } \\
\text { impact on customer satisfaction in e-commerce }\end{array}$ & Accepted & 0.007 & Significant \\
\hline $\begin{array}{l}\text { H1c: The Product Risk strategies have significant and positive } \\
\text { impact on customer satisfaction in e-commerce }\end{array}$ & Accepted & 0.000 & Significant \\
\hline $\begin{array}{l}\text { H1d: The Privacy Risk strategies have significant and positive } \\
\text { impact on customer satisfaction in e-commerce }\end{array}$ & Accepted & 0.000 & Significant \\
\hline $\begin{array}{l}\text { H1e: The Time Risk strategies have significant and positive } \\
\text { impact on customer satisfaction in e-commerce }\end{array}$ & Accepted & 0.003 & Significant \\
\hline $\begin{array}{l}\text { H2a: The involvement moderate the relationship between } \\
\text { Perceived Risk strategies and customer satisfaction in e-commerce }\end{array}$ & Accepted & 0.000 & Significant \\
\hline $\begin{array}{l}\text { H2b: The involvement moderate the relationship between Price } \\
\text { Risk strategies and customer satisfaction in e-commerce }\end{array}$ & Accepted & 0.000 & Significant \\
\hline $\begin{array}{l}\text { H2c: The involvement moderate the relationship between Product } \\
\text { Risk strategies and customer satisfaction in e-commerce }\end{array}$ & Accepted & 0.001 & Significant \\
\hline $\begin{array}{l}\text { H2d: The involvement moderate the relationship between Privacy } \\
\text { Risk strategies and customer satisfaction in e-commerce }\end{array}$ & Accepted & 0.000 & Significant \\
\hline $\begin{array}{l}\text { H2e: The involvement moderate the relationship between Time } \\
\text { Risk strategies and customer satisfaction in e-commerce }\end{array}$ & Accepted & 0.003 & Significant \\
\hline $\begin{array}{l}\text { H3a: The propensity to take risk moderate the relationship } \\
\text { between Perceived Risk strategies and customer satisfaction in e- } \\
\text { commerce }\end{array}$ & Accepted & 0.000 & Significant \\
\hline $\begin{array}{l}\text { H3b: The propensity to take risk moderate the relationship } \\
\text { between Price Risk strategies and customer satisfaction in e- } \\
\text { commerce }\end{array}$ & Accepted & 0.000 & Significant \\
\hline $\begin{array}{l}\text { H3c: The propensity to take risk moderate the relationship } \\
\text { between Product Risk strategies and customer satisfaction in e- } \\
\text { commerce }\end{array}$ & Accepted & 0.002 & Significant \\
\hline $\begin{array}{l}\text { H3d: The propensity to take risk moderate the relationship } \\
\text { between Privacy Risk strategies and customer satisfaction in e- } \\
\text { commerce }\end{array}$ & Accepted & 0.003 & Significant \\
\hline $\begin{array}{l}\text { H3e: The propensity to take risk moderate the relationship } \\
\text { between Time Risk strategies and customer satisfaction in e- } \\
\text { commerce }\end{array}$ & Accepted & 0.000 & Significant \\
\hline
\end{tabular}

\section{Conclusions}

Theories exist to discuss the theory of perceived risk, but no theory deals with questions of change in the perceived risk while using the Internet. The development of assumptions of this study's questionnaire, tours around five risks dimensions in electronic commerce. These dimensions were indicative of a change in Internet user's perceptions. Thus, we realized that what the characteristics of risk influence on customer purchase perception are. Customer satisfaction is one of the major factors studied by current research. The study represents different risk strategies which organizations should understand and provide security to their customers so that they get more involved with online services and encourage propensity to take risk which leads toward customer satisfaction and their repeat purchases. In each risk situation it is revealed that the purchase of a book is significantly higher than buying a laptop. This would mean that if transaction is less risky for customer, they don't want to share their credit card number and their personal information online. This is because of the risk are 


\section{INSIGHTS INTO REGIONAL DEVELOPMENT}

ISSN 2669-0195 (online) http://jssidoi.org/jesi/ 2020 Volume 2 Number 4 (December)

http://doi.org/10.9770/IRD.2020.2.4(4)

less cautious during their online transactions. Indeed, risks related to learning (lost time) and consumption patterns (product risk and intimacy) are based on customer satisfaction. If customers are satisfied with their internet transactions, they graduly become risk takers. The present study examined the impact of risk taking strategies which involved perceived, product, price, privacy and time risk security and investigated these strategies' influence on customer satisfaction. The study explained that these strategies (confidentiality, time security, no visual distortion of product) taken by organizations have major influence on customer satisfaction and this relationship is influenced by customer involvement and their propensity to take risk variables. Many sites provide clear information on safety, but more than half do not provide this information clearly and in a way that is sufficiently accessible. It is therefore imperative for merchants and retailers on the web to review the usability of their sites to put forward safety tools that would be visible to all users such as signs and labels and certifications. It is important for the organizations to build their security systems and provide the customers a good experience and a less risky online environment so that the more they get involved with the product the more they will be satisfied and repurchase it. Future studies should include more risk dimensions and also should increase the study sample which will be helpful to increase the generalizability of study.

\section{References}

Ariff, M.S.M, Sylvester, M., Zakuan N, Ismail, K. \& Ali, K.M. (2014). Consumer Perceived Risk, Attitude and Online Shopping Behaviour; Empirical Evidence from Malaysia, IOP Conference Series: Materials Science And Engineering

Bateson, John E. G. \& Hoffman, K. Douglas. (2001). Marketing Service: Bookman.

Bianchi \& Mathews. (2016). Internet Marketing and Export Market Growth in Chile. Journal of Business Research 69, $426-434$.

Choi, H., Kim, Y. \& Kim, J. (2011). Driving Factors of Post Adoption Behavior in Mobile Data Services. Journal of Business Research, 64(11), 1212-1227.

Cunningham, L.F., Gerlach, J.H., Harper, M.D., \& Young, C.E. (2005). Perceived Risk and the Consumer Buying Process: Internet Airline Reservations. International Journal of Service Industry Management, 16(4), 357-372.

Darsono, J.T., Susana, E., Prihantono, E. Y., Kasim, E.S. 2019. Strategic policies for small and medium businesses in marketing through ecommerce. Entrepreneurship and Sustainability Issues, 7(2), 1230-1245. http://doi.org/10.9770/jesi.2019.7.2(30)

Engel, James F., Blackwell, Roger D. \& Miniard, Paul W. (1995). Consumer Behaviour. 8. Ed. Orlando: The Dryden Press. 951 p. Bibliography: p. $441-442$.

Gierl, H., Hammer, C. (2003). Fear of Loss of Anonymity on the Internet and Consumers' Reactions: An Empirical Investigation. Yearbook of Marketing and Consumer Research, 1, 89-106.

Kim, E., Hong, T. (2010). Segmentating Customers in Online Stores from Factors That Affect the Customer's Intention to Purchase, pp. 383-388

Kim, L.H., Kim, D.J., \& Leong, J.K. (2005). The Effect Of Perceived Risk On Purchase Intention In Purchasing Airline Tickets Online, Journal Of Hospitality \& Leisure Marketing, 13(2), 33-53.

Klein, H. E. \& Sterk, E.C. (2003). "At Risk" Women Who Think That They Have No Chance Of Getting Hiv: Self-Assessed Perceived Risks. Woman and Health, 38(2), 47-63.

Kovacs, M. \& Farias, H. (2002). Perceived Risks and Ways to Purchase: The Duality versus Internet Consumers Online. Journal of Economics and Management, 1(2), April / June

Kuo Y F, Hu T L., \& Yang, S. C. (2013). Effects of Inertia and Satisfaction in Female Online Shoppers on Repeat-Purchase Intention. Managing Service Quality: An International Journal, 168-187.

Laroche, M., Bergeron, J. \& Goutaland, C. (2004). How Intangibility Affects Perceived Risk: The Moderating Role Of Knowledge And Involvement. The Journal of Services Marketing, 17(2/3), 122-141.

Lim, N. (2003). Consumer Perceived Risk: Sources Versus Consequences, Electronic Consumer Research And Applications, 2 , $216-28$.

Lim,' Y. J, Osman, A, Salahuddin, S.N, Romle A. R, \& Abdullah. S. (2016). Factors Influencing Online Shopping Behavior: The Mediating Role of Purchase Intention, Procedia Economics and Finance, 32, 401- 410.

Mccole, P., Ramsey, E. \& Williams, J. (2010). Trust Considerations On Attitudes Towards Online Purchasing: The Moderating Effect of Privacy and Security Concerns, Journal of Business Research, 63(9/10), 1018-24.

Mercado \& Rajagopal. (2015). Driving Consumers toward Online Retailing Technology: Analyzing Myths and Realities. Journal of Transnational Management, 20, 155-171.

Mitchell, V.-W. (1998). A Role for Consumer Risk Perceptions in Grocery Retailing. British Food Journal, 4, 171-183.

Mitchell, V.-W. \& Greatorex, M. (1990). Consumer Purchasing In Foreign Countries: The Perceived Risk Perspective. International Journal of Advertising, 9(4), 295-307.

Mou, Shin \& Cohen. (2015). Trust and Risk in Consumer Acceptance of E-Services. Electronic Commerce Research, 17, $255-288$. https://doi.org/10.1007/s10660-015-9205-4 
INSIGHTS INTO REGIONAL DEVELOPMENT

ISSN 2669-0195 (online) http://jssidoi.org/jesi/ 2020 Volume 2 Number 4 (December)

http://doi.org/10.9770/IRD.2020.2.4(4)

Oliver, Richard L. (1997) Satisfaction: A Behavioural Perspective On The Consumer. New York: Mcgraw-Hill Company.

Park, I., Bhatnagar, A. \& Rao, H.R. (2010). Assurance Seals, On-Line Customer Satisfaction, and Repurchase Intention, International Journal of Electronic Commerce, 14(3), 11-34.

Ranaweera. (2016). Perspective of Trust towards E-Government Initiatives in Sri Lanka. Springerplus 5. https://doi.org/10.1186/s40064015-1650-y

Santos, J. (2002). From Intangibility To Tangibility On Service Quality Perceptions: A Comparison Study Between Consumers And Service Providers In Four Service Industries, Managing Service Quality, 12(5), 292-302.

Schhiffman J.B., \& Kanuk. L. L. (1997). Consumer Behavior Published By Prentice Hall Sixth Edition, 446p.

Sobihah, M., Mohamad, M., Ali, N.A.M, \& Ismail, W.Z.W. (2015), E-Commerce Service Quality on Customer Satisfaction, Belief and Loyalty: A Proposal, Mediterranean Journal of Social Sciences, Vol. 2

Solomon. (2002). The Consumer Behaviour: Buying, Having Being. 5 Ed. Porto Alegre: Bookman, 446p. Bibliography: p.216-217

Solomon, Michael R. (1998). Consumer Behaviour: Buying, Having and Being. 4. Ed. New Jersey: Prentice Hall. 640 p: p.280-281

Son, M. \& Han, K. (2011). Beyond The Technology Adoption: Technology Readiness Effects on Post-Adoption Behavior, Journal of Business Research, 64(11), 1178-82.

Wu, George, Jiao, Z., \& Richard. G. (2004). Decision under Risk, In Blackwell Handbook of Judgment and Decision Making, Nigel Harvey \& Derek Koehler, Eds. London: Blackwell Publishing.

Zeithaml, V.A., \& Bitner, M.J. (2003). Services Marketing: Integrating Customer Focus across the Firm, 3rd Ed., Mcgraw-Hill, New York, Ny.

Kiran JAVARIA is Lead Learning Advisor of OM International Learning Partner Asia-e-University, Malaysia. She is also Lecturer at School of Accountancy and Finance, University of Lahore, Islamabad Campus, Pakistan. Her specialization is in finance, Islamic banking and research based topics. Her PhD is in Islamic Banking \& Finance from Asia e University, Kuala Lumpur, Malaysia. She has authored several research papers which have been published in some leading international journals and presented at conferences. Her recent publications are in international journals i.e. "Problems and Perspectives in Management" and "Global Advanced Research Journals". Her recent publications have been highly recommended and cited globally.

ORCID ID: http://orcid.org/0000-0002-6147-5283

Prof. Dr. Omar MASOOD (PhD UK) is CEO OM International Learning Partner Asia-e-University, Malaysia. He is also Professor at School of Accountancy and Finance, University of Lahore Islamabad, Pakistan. He is former Director of the Centre of Islamic Banking and Finance at the Royal Docks Business School, University of East London, United Kingdom. He had worked with financial advisors like Goldman Sachs. He is a lead advisor and trainer in the area of Islamic banking and finance worldwide, to financial as well as academic institutions. He is a founding member of Research Centers in Malaysia. Dr. Masood supervises PhD dissertations in the areas of banking, finance, corporate financial management, risk management, fund management, banking regulations, Islamic banking, international business and other finance, accounting and management related subjects, with a number of successful completions. He holds visiting professorships in universities all over the world, and has served as an advisor/consultant to a number of governments including the Turkish and Saudi Arabian. Dr. Masood has authored over a hundred peer reviewed research papers which have been published in international journals and presented at conferences. A number of his papers have been listed as highly recommended and most read by leading publishers. He has also authored a number of books, including the bestselling "Truth about the Global Financial Crisis" and the text book "Multiplying Money through Financial Management”.

ORCID ID: http://orcid.org/0000-0001-5481-4032

Fernando GARCÍA: Department of Economics and Social Sciences, Universitat Politecnica de Valencia, Valencia, Spain. ORCID ID: http://orcid.org/0000-0001-6364-520X

Make your research more visible, join the Twitter account of INSIGHTS INTO REGIONAL DEVELOPMENT: @IntoInsights

Copyright (C) 2020 by author(s) and VsI Entrepreneurship and Sustainability Center

This work is licensed under the Creative Commons Attribution International License (CC BY). http://creativecommons.org/licenses/by/4.0/

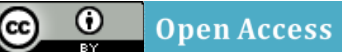

